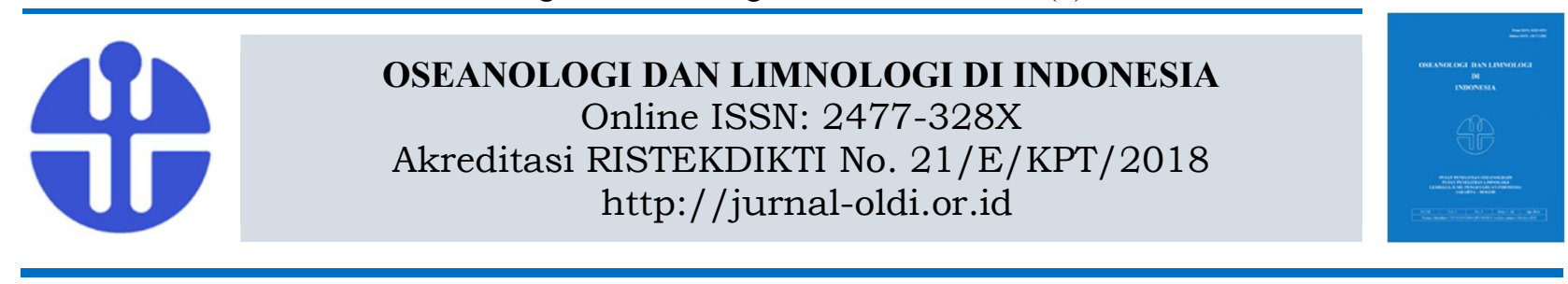

\title{
Konsumsi Oksigen Ikan Uceng Nemacheilus fasciatus (Valenciennes, 1846) pada Kondisi Padat Tebar yang Berbeda
}

\author{
Aliati Iswantari ${ }^{1}$, Kurniawan $^{2}$, Bambang Priadi $^{3}$, Vitas Atmadi Prakoso ${ }^{3}$ dan Anang Hari Kristanto ${ }^{3}$ \\ ${ }^{1}$ Departemen Manajemen Sumberdaya Perairan, Fakultas Perikanan dan Ilmu Kelautan, \\ Institut Pertanian Bogor, Bogor \\ ${ }^{2}$ Badan Riset dan Sumberdaya Manusia Kelautan dan Perikanan, \\ Kementerian Kelautan dan Perikanan, Jakarta \\ ${ }^{3}$ Balai Riset Perikanan Budidaya Air Tawar dan Penyuluhan Perikanan, Bogor \\ Email: vitas.atmadi@gmail.com
}

Submitted 08 February 2019. Reviewed 30 April 2019. Accepted 29 May 2019.

DOI: 10.14203/oldi.2019.v4i2.245

\begin{abstract}
Abstrak
Pada sistem budidaya, pertumbuhan ikan dipengaruhi oleh padat tebar. Salah satu cara memprediksi pengaruh padat tebar terhadap pertumbuhan adalah dengan menentukan laju metabolisme ikan melalui pengukuran konsumsi oksigen. Pada ikan Uceng Nemacheilus fasciatus (Valenciennes, 1846), informasi tersebut belum tersedia. Oleh karena itu, penelitian ini dilakukan untuk menganalisis pengaruh padat tebar terhadap konsumsi oksigen pada ikan Uceng. Penelitian ini dilakukan di Balai Riset Perikanan Budidaya Air Tawar dan Penyuluhan Perikanan, Bogor pada bulan Mei 2018. Ikan Uceng (panjang total: 5,79 \pm 0,47 cm, bobot: $1,32 \pm 0,34 \mathrm{~g})$ diamati konsumsi oksigennya dalam tiga padat tebar yang berbeda $(5,10$, dan 15 ekor $/ \mathrm{L})$ menggunakan respirometer tertutup (volume: $1,4 \mathrm{~L}$ ) dengan masing-masing perlakuan terdiri dari tiga ulangan. Pengukuran konsumsi oksigen dilakukan pada kondisi normoksia dan hipoksia. Selain itu, tingkah laku dan laju ventilasi juga diamati dan dicatat sesuai dengan perlakuan. Hasil penelitian menunjukkan bahwa konsumsi oksigen tertinggi ikan Uceng didapatkan pada perlakuan padat tebar 5 ekor $/ \mathrm{L}(1250,6 \pm 128,4 \mathrm{mg} \mathrm{O} / \mathrm{kg} / \mathrm{jam})$ yang berbeda nyata dengan perlakuan 10 ekor $/ \mathrm{L}\left(626,9 \pm 46,7 \mathrm{mg} \mathrm{O}_{2} / \mathrm{kg} / \mathrm{jam}\right)$ dan 15 ekor $/ \mathrm{L}(596,9 \pm 48,9 \mathrm{mg}$ $\mathrm{O}_{2} / \mathrm{kg} / \mathrm{jam}$ ). Sementara itu, konsumsi oksigen ikan Uceng pada kondisi hipoksia mengalami penurunan secara signifikan dibandingkan dengan pada kondisi normoksia, yang ditandai dengan menurunnya aktivitas renang ikan Uceng. Meskipun laju ventilasi pada kondisi hipoksia mengalami penurunan, namun nilainya tidak berbeda nyata dengan pada kondisi normoksia. Hasil penelitian ini memberikan informasi bahwa peningkatan padat tebar dan kondisi hipoksia pada ikan Uceng menyebabkan penurunan tingkat konsumsi oksigen, kadar oksigen kritis ikan Uceng adalah sekitar 3,1 mg/L.
\end{abstract}

Kata kunci: Nemacheilus fasciatus, padat tebar, konsumsi oksigen.

\section{Abstract}

Oxygen Consumption of Barred Loach Nemacheilus fasciatus (Valenciennes, 1846) under Different Stocking Densities. In aquaculture system, fish growth is affected by stocking densities. One way to predict the effect of stocking density on growth is to determine fish metabolic rate through oxygen consumption measurements. In Barred loach Nemacheilus fasciatus (Valenciennes, 1846), the information was scarce on oxygen consumption. This study was to analyze the effect of stocking density on oxygen consumption in Barred loach conducted at Research Institute for Freshwater Aquaculture and Fisheries Extension, Bogor in May 2018. Barred loach (total length: $5.79 \pm 0.47 \mathrm{~cm}$, weight: $1.32 \pm 0.34 \mathrm{~g}$ ) was observed 
Iswantari et al.

its oxygen consumption on three different stocking densities (5, 10, and 15 fish/L) by using closed respirometers (volume: $1.4 \mathrm{~L}$ ) with three replications of each treatment. Measurement of oxygen consumption was carried out under normoxia and hypoxia conditions. In addition, fish behavior and ventilation rate were also observed and recorded according to treatment. The results showed that the highest oxygen consumption of barred loach was found in the stocking density of $5 \mathrm{fish} / \mathrm{L}(1250.6 \pm 128.4 \mathrm{mg} \mathrm{O} / \mathrm{kg} / \mathrm{h})$ which was significantly different from the stocking density of $10 \mathrm{fish} / \mathrm{L}(626.9 \pm 46.7 \mathrm{mg} \mathrm{O} / \mathrm{kg} / \mathrm{h})$ and $15 \mathrm{fish} / \mathrm{L}(596.9 \pm$ $48.9 \mathrm{mg} \mathrm{O}_{2} / \mathrm{kg} / \mathrm{h}$ ). Meanwhile, oxygen consumption of barred loach under hypoxic conditions decreased significantly compared to normoxic conditions, which was marked by a decrease in their swimming activities. Although the ventilation rate in hypoxic conditions has decreased, the value was not significantly different from those of normoxia condition. Results of this study provide information that an increase in stocking density and hypoxic conditions in barred loach caused a decrease in oxygen consumption rates. In addition, this study showed that the critical oxygen level for barred loach was around $3.1 \mathrm{mg} / \mathrm{L}$.

Keywords: Nemacheilus fasciatus, stocking density, oxygen consumption.

\section{Pendahuluan}

Ikan Uceng Nemacheilus fasciatus (Valenciennes, 1846) adalah salah satu spesies ikan air tawar asli di Indonesia yang prospektif sebagai bahan pangan. Jenis ikan ini memiliki harga jual yang tinggi, baik dalam bentuk segar maupun olahan (Wardhana \& Riana, 2015; Prakoso et al., 2016; Utami, 2017). Namun demikian, ketersediaan ikan ini di pasar sebagian besar masih tergantung dari hasil tangkapan alam.

Pada sistem budidaya, padat tebar merupakan salah satu faktor yang memengaruhi pertumbuhan ikan dalam sistem budidaya. Parameter padat tebar terkait erat dengan optimalnya pertumbuhan dan kelangsungan hidup ikan (Ronald et al., 2014). Pengaruh padat tebar terhadap pertumbuhan telah dipelajari pada beberapa spesies ikan air tawar, seperti ikan Nila Oreochromis niloticus (El-Sayed, 2002; Rahman et al., 2016), Lalawak Barbonymus balleroides (Arifin et al., 2017a), Lele Clarias batrachus (Sahoo et al., 2004), dan Amur sturgeon Acipenser schrenckii (Li et al., 2012). Pengaruh padat tebar terhadap pertumbuhan ikan Uceng telah diamati oleh Prakoso et al. (2016). Namun demikian, pengaruh padat tebar terhadap konsumsi oksigen pada ikan Uceng belum pernah diteliti. Studi sebelumnya, terkait pengaruh padat tebar terhadap metabolisme dan konsumsi oksigen, telah diamati pada beberapa spesies ikan, seperti Arctic Charr Salvelinus alpinus (Jorgensen et al., 1993), Black Porgy Acanthopagrus schelegelii (Chang et al., 2005), Belanak Chelon labrosus (De las Heras et al., 2015), Meagre Argyrosomus regius (MillanCubillo, 2016), dan Amur Sturgeon Acipenser schrenckii (Ren et al., 2017).

Informasi dan penelitian terkait proses domestikasi ikan Uceng masih sangat terbatas sehingga upaya budidayanya juga masih belum berkembang. Oleh karena itu, kajian biologi ikan 80
Uceng, khususnya aspek fisiologis (tingkat konsumsi oksigen) perlu dilakukan. Penelitian ini dilakukan dengan tujuan untuk memperoleh informasi tentang konsumsi oksigen dari ikan Uceng pada tiga kondisi padat tebar yang berbeda. Hasil penelitian ini diharapkan dapat dimanfaatkan untuk mendukung optimalisasi manajemen pemeliharaan ikan Uceng.

\section{Metodologi}

Penelitian ini dilakukan di Balai Riset Perikanan Budidaya Air Tawar dan Penyuluhan Perikanan (BRPBATPP), Bogor pada bulan Mei 2018. Ikan uji (panjang total: $5,79 \pm 0,47 \mathrm{~cm}$ dan bobot: 1,32 $\pm 0,34 \mathrm{~g})$ dipelihara pada sistem resirkulasi indoor sebelum percobaan. Selama pemeliharaan, ikan diberi pakan berupa pelet (protein $39-41 \%$ dan lemak $5 \%$ ) sebanyak $2 \%$ per hari dari biomassa ikan tersebut. Pakan diberikan pada pagi dan sore hari. Sehari sebelum percobaan, ikan dipuasakan selama 24 jam untuk menghindari pengaruh pakan terhadap metabolisme.

Percobaan untuk mengukur konsumsi oksigen dilakukan dalam respirometer tertutup (volume: 1,4 L). Alat pengukur dan sensor oksigen (Trans Instrument HD3030, Singapore) dihubungkan pada respirometer untuk mengukur konsentrasi oksigen terlarut. Percobaan ini dilakukan pada tiga perlakuan padat tebar yang berbeda dan masing-masing perlakuan dibuat tiga ulangan. Penentuan padat tebar didasarkan pada penelitian sebelumnya, yang mana diperoleh nilai padat tebar terbaik untuk pertumbuhan ikan Uceng adalah 5 ekor/L (Subagja et al., 2019). Oleh karena itu, padat tebar yang digunakan pada penelitian ini yaitu 5, 10, dan 15 ekor/L. Pada penelitian ini, suhu air di respirometer dijaga konstan pada suhu $28,5 \pm$ $0,3^{\circ} \mathrm{C}$ dengan kisaran $\mathrm{pH} 7,7 \pm 0,5$. Pengukuran konsentrasi oksigen terlarut dilakukan setiap 10 menit selama tiga jam waktu pengamatan. Selain 
Oseanologi dan Limnologi di Indonesia 2019 4(2):79-87

tingkat konsumsi oksigen, dilakukan pengamatan tingkah laku ikan Uceng serta pengukuran frekuensi bernafas/laju ventilasi (breathing frequency/ventilation rates) menggunakan metode dari Wares \& Igram (1979). Konsumsi oksigen dihitung dengan rumus Kawamoto (1977) sebagai berikut:

$$
O C=\left(D O_{0}-D O_{t}\right) x \frac{V}{t \times W}
$$

\begin{tabular}{|c|c|c|}
\hline \multicolumn{2}{|c|}{ Keterangan: } & \\
\hline$O C$ & 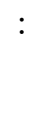 & $\begin{array}{l}\text { konsumsi oksigen yang dinyatakan } \\
\text { dalam miligram oksigen per jam } \\
\text { per kilogram ikan }\left(\mathrm{mg} \mathrm{O}_{2} / \mathrm{kg} / \mathrm{jam}\right)\end{array}$ \\
\hline $\mathrm{DO}_{0}$ & : & oksigen terlarut awal $\left(\mathrm{mg} \mathrm{O}_{2} / \mathrm{L}\right)$ \\
\hline$D O_{t}$ & : & $\begin{array}{l}\text { oksigen terlarut setelah } \mathrm{t} \text { jam (mg } \\
\left.\mathrm{O}_{2} / \mathrm{L}\right)\end{array}$ \\
\hline$V$ & : & volume air pada respirometer $(\mathrm{L})$ \\
\hline$t$ & : & $\begin{array}{l}\text { waktu yang berlalu untuk ikan yang } \\
\text { mengonsumsi oksigen (jam) }\end{array}$ \\
\hline$W$ & & bobot ikan (kg) \\
\hline
\end{tabular}

Sebagai data pendukung, kadar oksigen kritis juga diukur dalam penelitian ini. Pörtner et al. (1985) menyatakan bahwa kadar oksigen kritis merupakan kadar oksigen terlarut pada saat nilai konsumsi oksigen/laju metabolisme ikan lebih rendah daripada laju metabolisme standar (standard metabolic rate) saat terjadi deplesi oksigen dari tingkat jenuh ke kondisi hipoksia. Berdasarkan referensi tersebut, kadar oksigen kritis pada penelitian ini ditentukan dengan menghitung konsumsi oksigen/laju metabolisme standar dan konsumsi oksigen saat deplesi oksigen, sehingga diperoleh kadar oksigen terlarut ikan Uceng lebih rendah dari laju metabolisme standar. Kadar oksigen terlarut tersebut ditentukan sebagai kadar oksigen kritis.

Data konsentrasi oksigen terlarut untuk menentukan tingkat konsumsi oksigen dikelompokkan menjadi dua, yaitu kondisi oksigen normal/normoksia (normoxia) pada saat nilai oksigen terlarut di atas $5 \mathrm{mg} / \mathrm{L}$ dan saat kondisi oksigen rendah/hipoksia (hypoxia) pada saat nilai oksigen terlarut lebih rendah dari $5 \mathrm{mg} / \mathrm{L}$ (Pichavant et al., 2000; 2001). Selanjutnya, data konsumsi oksigen berdasarkan perbedaan padat tebar dianalisis dengan ANOVA satu arah dengan nilai tingkat kepercayaan $5 \%(\mathrm{P}<0,05)$, sedangkan data konsumsi oksigen pada kondisi normoksia dan hipoksia dianalisis dengan uji-t dengan nilai tingkat kepercayaan $1 \%(\mathrm{P}<0,01)$. Kedua uji tersebut dilakukan menggunakan perangkat lunak statistik PASW Statistics 18.

\section{Hasil}

Data hasil pengukuran konsumsi oksigen pada ikan Uceng berdasarkan padat tebar disajikan pada Tabel 1. Hasil pengamatan ini (Tabel 1) menunjukkan bahwa nilai konsumsi oksigen cenderung menurun seiring dengan meningkatnya padat tebar. Pada kondisi normoksia, nilai konsumsi oksigen ikan Uceng pada perlakuan padat tebar 5 ekor/L lebih tinggi dan berbeda nyata dengan perlakuan lainnya $(\mathrm{P}<0,05)$, sedangkan nilai konsumsi oksigen ikan Uceng pada perlakuan padat tebar 10 dan 15 ekor/L tidak berbeda nyata $(\mathrm{P}>0,05)$. Pada kondisi hipoksia, nilai konsumsi oksigen tidak berbeda nyata pada ketiga perlakuan. Nilai konsumsi oksigen antara kondisi normoksia dan hipoksia berbeda nyata pada ketiga perlakukan padat tebar. Pada kondisi normoksia, nilai konsumsi oksigen ikan Uceng lebih tinggi pada kondisi hipoksia $(\mathrm{P}<0,01)$.

Hasil pengamatan secara visual menunjukkan bahwa aktivitas renang ikan Uceng menurun dengan semakin menurunnya oksigen terlarut ke kondisi hipoksia (oksigen terlarut $<5$ $\mathrm{mg} / \mathrm{L}$ ). Setelah oksigen terlarut menjadi lebih rendah dari $3,5 \mathrm{mg} / \mathrm{L}$, ikan mulai kehilangan keseimbangan. Data laju ventilasi ikan Uceng pada padat tebar 5, 10, dan 15 ekor/L disajikan pada Tabel 2. Nilai rerata laju ventilasi ikan Uceng tidak berbeda nyata antara pada kondisi normoksia dan hipoksia, maupun antara ketiga padat tebar $(\mathrm{P}>0,05)$. Sementara itu, nilai konsumsi oksigen per nafas pada ketiga perlakuan padat tebar pada kondisi hipoksia mengalami penurunan yang sangat nyata dibandingkan pada kondisi normoksia $(\mathrm{P}<0,01)$. Pada kondisi normal (normoksia), nilai konsumsi oksigen dalam sekali bernafas pada ikan Uceng ditemukan tertinggi pada padat tebar 5 ekor/L, berbeda nyata dengan padat tebar 10 dan 15 ekor/L $(\mathrm{P}<0,05)($ Tabel 2).

Sementara itu, pada pengamatan kadar oksigen kritis, hasil penelitian ini menunjukkan bahwa kadar oksigen kritis ikan Uceng yaitu 3,10 $\pm 0,26 \mathrm{mg} / \mathrm{L}, 2,79 \pm 0,36 \mathrm{mg} / \mathrm{L}$, dan 2,59 $\pm 0,44$ $\mathrm{mg} / \mathrm{L}$ masing-masing untuk padat tebar 5,10 , dan 15 ekor/L. Namun, nilai tersebut tidak berbeda Nyata $(\mathrm{P}>0,05)$. 
Iswantari et al.

Tabel 1. Konsumsi oksigen ikan Uceng Nemacheilus fasciatus pada tiga kepadatan yang berbeda dan pada kondisi normoksia dan hipoksia.

Table 1. Oxygen consumption of Barred Loach Nemacheilus fasciatus at three different stocking densities and during normoxia and hypoxia.

\begin{tabular}{ccc}
\hline \multirow{3}{*}{ Stocking density (fish/L) } & \multicolumn{2}{c}{ Oxygen consumption $(\mathrm{mg} \mathrm{O} / \mathrm{kg} / \mathrm{h})$} \\
\cline { 2 - 3 } & Normoxia & Hypoxia \\
\hline 5 & $1250.6 \pm 128.4^{\mathrm{b}^{* *}}$ & $47.3 \pm 21 . \mathrm{5}^{\mathrm{x}^{*}}$ \\
10 & $626.9 \pm 46.7^{\mathrm{a}^{* *}}$ & $51.8 \pm 28.4^{\mathrm{x}^{*}}$ \\
15 & $596.9 \pm 48.9^{\mathrm{a}^{* *}}$ & $40.9 \pm 20.4^{\mathrm{x}^{*}}$ \\
\hline
\end{tabular}

Keterangan: Nilai merupakan rerata $\pm \mathrm{SD}(\mathrm{n}=3)$. Superskrip alfabet yang berbeda menunjukkan nilai berbeda nyata antara padat tebar yang berbeda ( $\mathrm{P}<0,05$, ANOVA satu arah). Superskrip bintang menunjukkan nilai berbeda nyata antara kondisi normoksia dan hipoksia $(\mathrm{P}<0,01$, uji-t).

Description: Values are the mean $\pm \mathrm{SD}(\mathrm{n}=3)$. Different alphabet superscript showed significant difference values between different stocking densities $(\mathrm{P}<0.05$, one-way ANOVA). Asterisk superscript showed significant difference values between normoxia and hypoxia $(\mathrm{P}<0.01$, t-test $)$.

Tabel 2. Laju ventilasi dan konsumsi oksigen dalam sekali bernafas ikan Uceng Nemacheilus fasciatus pada tiga kepadatan yang berbeda dan pada kondisi normoksia dan hipoksia.

Table 2. Ventilation rates and oxygen consumption per breath of Barred Loach Nemacheilus fasciatus at three different stocking densities and during normoxia and hypoxia.

\begin{tabular}{ccccc}
\hline \multirow{2}{*}{$\begin{array}{c}\text { Stocking density } \\
(\text { fish/L) }\end{array}$} & \multicolumn{2}{c}{$\begin{array}{c}\text { Ventilation rates } \\
\text { (times/minute) }\end{array}$} & \multicolumn{2}{c}{$\begin{array}{c}\text { Oxygen consumption } \\
\text { per breath }\left(\mathrm{mg} \mathrm{O}_{2} / \mathrm{kg} / \mathrm{breath}\right)\end{array}$} \\
\cline { 2 - 5 } & Normoxia & Hypoxia & Normoxia & Hypoxia \\
\hline 5 & $117.7 \pm 12.7^{\mathrm{a}^{*}}$ & $95.0 \pm 8.7^{\mathrm{a}^{*}}$ & $10.69 \pm 1.25^{\mathrm{y}^{* *}}$ & $0.51 \pm 0.26^{\mathrm{k}^{*}}$ \\
10 & $103.3 \pm 10.7^{\mathrm{a}^{*}}$ & $98.0 \pm 7.2^{\mathrm{a}^{*}}$ & $6.14 \pm 1.05^{\mathrm{x}^{* *}}$ & $0.54 \pm 0.34^{\mathrm{k}^{*}}$ \\
15 & $116.7 \pm 5.9^{\mathrm{a}^{*}}$ & $99.7 \pm 14.6^{\mathrm{a}^{*}}$ & $5.11 \pm 0.17^{\mathrm{x}^{* *}}$ & $0.40 \pm 0.15^{\mathrm{k}^{*}}$ \\
\hline
\end{tabular}

Keterangan: Nilai merupakan rerata $\pm \mathrm{SD}(\mathrm{n}=3)$. Superskrip alfabet yang berbeda menunjukkan nilai berbeda nyata antara padat tebar yang berbeda ( $\mathrm{P}<0,05$, ANOVA satu arah). Superskrip bintang menunjukkan nilai berbeda nyata antara kondisi normoksia dan hipoksia $(\mathrm{P}<0,01$, uji-T).

Description: Values are the mean \pm SD $(n=3)$. Different alphabet superscript showed significant difference values between different stocking densities ( $\mathrm{P}<0.05$, one-way ANOVA). Asterisk superscript showed significant difference values between normoxia and hypoxia $(\mathrm{P}<0.01$, t-test $)$.

\section{Pembahasan}

Hasil penelitian ini menunjukkan bahwa pada kondisi normoksia, peningkatan padat tebar ikan Uceng menyebabkan penurunan tingkat konsumsi oksigen. Penurunan tingkat konsumsi oksigen karena peningkatan padat tebar juga ditemukan pada penelitian terdahulu pada ikan Arctic Charr Salvelinus alpinus (Jorgensen et al., 1993). Sementara itu, beberapa penelitian yang lain menunjukkan bahwa peningkatan padat tebar tidak memberikan pengaruh yang signifikan terhadap tingkat konsumsi oksigen, misalnya pada ikan Nila merah Oreochromis sp. (Suresh \& Lin, 1992),
Senegalese sole Solea senegalensis (Salas-Leiton et al., 2008), dan Atlantic Sturgeon

Acipenser oxyrinchus (Szczepkowski et al., 2011). Kondisi berbanding terbalik dengan hasil penelitian ini ditemukan pada ikan White Sturgeon Acipenser transmontanus (Ruer et al., 1987), dimana peningkatan padat tebar cenderung meningkatkan konsumsi oksigen. Berdasarkan informasi tersebut, diketahui bahwa konsumsi oksigen bervariasi pada spesies yang berbeda dalam merespon peningkatan padat tebar. Hal tersebut diduga karena tiap spesies memiliki respon yang berbeda dalam persaingan antar individu menghadapi peningkatan padat tebar. Menurut Mishrigi dan Kubo (1978), persaingan antar individu dapat memodifikasi aktivitas ikan dan 
Oseanologi dan Limnologi di Indonesia 2019 4(2):79-87

konsumsi oksigen, sehingga dapat dikatakan bahwa padat tebar dapat mempengaruhi metabolisme. Hal tersebut seperti yang ditemukan pada ikan Rainbow Trout Oncorhynchus mykiss (Laursen et al., 2013) dan Nila Oreochromis niloticus (Garcia-Trejo et al., 2016).

Konsumsi oksigen ikan Uceng pada konsisi hipoksia berbeda nyata lebih rendah dibandingkan pada kondisi normoksia. Hipoksia biasanya dianggap sebagai salah satu faktor pembatas dalam pertumbuhan ikan (Pichavant et al.. 2001). Menurut Jobling (1993) dan Petersen dan Gamperl (2010), pada kondisi hipoksia diperlukan pengurangan aktivitas atau komponen-komponen lainnya dari jumlah energi total untuk beradaptasi terhadap kondisi oksigen terlarut yang rendah dengan cara menurunkan proses metabolisme. Secara lebih detail, Richards (2011) menjelaskan bahwa pada kondisi hipoksia, kebutuhan adenosine trifosfat (ATP) sebagian ditutupi oleh proses seperti glikolisis yang memproduksi laktat atau melalui transfer fosfat langsung dari phosphorylated intermediates seperti creatine fosfat. Proses ini bergantung pada ketersediaan substrat dan kapasitas biokimia untuk memproduksi oxygen-independent ATP. Selanjutnya, ikan dapat melakukan pengurangan kebutuhan metabolisme melalui mekanisme penekanan tingkat metabolisme secara terkontrol. Penurunan konsumsi oksigen pada kondisi hipoksia ini juga terjadi pada ikan White Sturgeon Acipenser transmontanus (Burggren \& Randall, 1978), Gabus Channa striata (Lefevre et al., 2012), Rainbow Trout Oncorhynchus mykiss (Svendsen et al., 2012; Magnoni et al., 2018), dan Nila Oreochromis niloticus (Prakoso \& Chang, 2018).

Pada kondisi hipoksia, laju ventilasi ikan Uceng tidak berbeda nyata dengan kondisi normoksia. Menurut Perry et al. (2009), variasi laju ventilasi pada spesies ikan yang berbeda merupakan strategi dari masing-masing spesies untuk beradaptasi terhadap kondisi hipoksia, dimana strategi dilakukan dengan meningkatkan frekuensi pernapasan (hyperventilation) atau dengan menurunkan frekuensi pernapasan. Pada penelitian ini, meskipun laju ventilasi ikan Uceng tidak berbeda nyata antara normoksia dan hipoksia, akan tetapi dari nilai rerata laju ventilasi menunjukkan adanya kecenderungan ikan Uceng menurunkan frekuensi pernapasannya untuk beradaptasi pada kondisi hipoksia. Kondisi serupa terjadi pada ikan Patin Pangasianodon hypophthalmus (Lefevre et al., 2011), yaitu laju ventilasi pada kondisi hipoksia lebih rendah daripada kondisi normoksia. Kondisi yang berbeda ditemukan pada ikan Gulf killifish Fundulus grandis (Rees et al., 2009) dan ikan Mas Koki Carassius auratus (Tzaneva et al., 2011) dimana laju ventilasi pada kondisi hipoksia lebih tinggi dibandingkan daripada kondisi normoksia.

Penelitian sebelumnya menunjukkan padat tebar terbaik untuk pertumbuhan ikan Uceng adalah 5 ekor/L (Subagja et al., 2019). Hasil penelitian kali ini memperkuat hasil temuan tersebut. Pada penelitian ini, konsumsi oksigen dalam sekali bernafas ikan Uceng pada perlakuan padat tebar 5 ekor/L menunjukkan nilai yang berbeda nyata dengan perlakuan padat tebar 10 dan 15 ekor/L. Nilai tersebut menunjukkan bahwa di antara ketiga perlakuan tersebut laju metabolisme terbaik ada pada padat tebar 5 ekor/L. Berdasarkan hasil pengukuran konsumsi oksigen tersebut, padat tebar 5 ekor/L pada ikan Uceng akan menghasilkan performa pertumbuhan yang lebih baik dibandingkan ikan Uceng yang dipelihara dengan padat tebar yang lebih tinggi. Hasil penelitian ini menunjukkan bahwa terdapat hubungan antara konsumsi oksigen dan deplesi oksigen di dalam respirometer. Konsumsi oksigen ikan Uceng secara signifikan lebih besar saat normoksia dibandingkan saat hipoksia. Menurut Fry (1971), komponen utama pengeluaran energi metabolik adalah untuk aktivitas renang. Berdasarkan pengamatan secara visual, saat hipoksia terjadi penurunan aktivitas ikan Uceng. Jika dihubungkan dengan pernyataan tersebut, maka dapat diketahui bahwa ikan Uceng beradaptasi terhadap kondisi hipoksia dengan mengurangi aktivitasnya sehingga konsumsi oksigennya lebih rendah. Jika paparan hipoksia ini berlangsung lama, maka dapat berpengaruh negatif pada ikan, terutama dalam penurunan laju pertumbuhan ikan akibat aktivitas makan yang berkurang (Cech et al., 1984), sehingga berdampak pada pertumbuhan dan kelangsungan hidup ikan (Smith \& Able, 2003).

Berdasarkan data pengukuran tingkat konsumsi oksigen pada kondisi hipoksia, kadar oksigen kritis $\left(\mathrm{O}_{2 \text { crit }}\right)$ pada ikan Uceng dapat diprediksi. Menurut Jobling (1994), kadar oksigen kritis merupakan kadar oksigen saat ikan tidak mampu lagi mempertahankan pasokan oksigen yang memadai untuk kecukupan metabolisme tubuhnya. Hasil pengamatan menunjukkan bahwa kadar oksigen kritis ikan Uceng yaitu 3,10 $\pm 0,26$ $\mathrm{mg} / \mathrm{L}, 2,79 \pm 0,36 \mathrm{mg} / \mathrm{L}$, dan 2,59 $\pm 0,44 \mathrm{mg} / \mathrm{L}$ masing-masing untuk padat tebar 5, 10, dan 15 ekor/L. Namun, nilai tersebut tidak berbeda nyata ( $>0$ 0,05). Randall (1982) menyatakan bahwa tingkat oksigen terlarut letal bagi ikan berbedabeda, tergantung spesies dan tingkat adaptasinya. Jika dibandingkan dengan penelitian terdahulu, variasi tinggi rendahnya nilai kadar oksigen kritis 
Iswantari et al.

dipengaruhi oleh faktor suhu (Ott et al., 1980; Rombough, 1988, Mamun et al., 2013) dan stres akibat kondisi hipoksia (Borger et al., 1998; Herbert \& Steffensen, 2005; Arifin et al., 2017b). Cruz-Neto \& Steffensen (1997) mengemukakan bahwa kadar oksigen kritis ini dapat digunakan sebagai pendekatan untuk mengetahui ambang batas bawah kadar oksigen terlarut yang berpotensi memiliki pengaruh negatif terhadap pertumbuhan dan reproduksi spesies ikan di dalam sistem budidaya.

\section{Kesimpulan}

Padat tebar yang semakin tinggi akan menyebabkan tingkat konsumsi oksigen pada ikan Uceng semakin rendah. Perlakuan padat tebar 5 ekor/L menghasilkan nilai rerata konsumsi oksigen tertinggi dan berbeda nyata dengan perlakuan padat tebar 10 dan 15 ekor/L. Berdasarkan pengamatan kadar oksigen kritis pada ikan Uceng, disarankan kondisi oksigen terlarut dalam sistem pemeliharaan ikan Uceng dipertahankan tidak mendekati atau berada di bawah 3,1 $\mathrm{mg} / \mathrm{L}$ agar tidak muncul dampak negatif hipoksia pada kelangsungan hidup ikan Uceng. Di samping itu, data kadar oksigen kritis ini juga dapat digunakan sebagai acuan dalam kegiatan transportasi tertutup pada ikan Uceng, sehingga penyesuaian kepadatan ikan saat pengiriman dengan lama waktu transportasi dapat dilakukan agar tidak melampaui kadar oksigen kritis yang berpotensi menyebabkan ikan stres atau mati karena oksigen terlarut yang sangat rendah.

\section{Persantunan}

Penelitian ini merupakan bagian dari kerjasama antara Balai Riset Perikanan Budidaya Air Tawar dan Penyuluhan Perikanan dengan Dinas Kelautan dan Perikanan Kabupaten Temanggung yang dibiayai oleh DIPA APBD Dinas Kelautan dan Perikanan Kabupaten Temanggung Tahun 2018. Penulis mengucapkan terima kasih kepada Bapak Jojo Subagja, Bapak Otong Zenal Arifin, Dedi, Bapak Muhamad Hadi, dan Dinas Kelautan dan Perikanan Kabupaten Temanggung atas kontribusinya selama penelitian berlangsung.

\section{Daftar Pustaka}

Arifin, O. Z., Subagja, J., Prakoso, V. A., \& Suhud, E. H. (2017a). Effect of stocking density on growth performance of domesticated barb
(Barbonymus balleroides). Indonesian Aquaculture Journal, 12(1), 1-6.

Arifin, O. Z., Prakoso, V. A., \& Pantjara, B. (2017b). Ketahanan ikan tambakan (Helostoma temminkii) terhadap beberapa parameter kualitas air dalam lingkungan budidaya. Jurnal Riset Akuakultur, 12(3), 241-251.

Borger, R., de Boeck, G., van Auderke, J., Dommisse, R., Blust, R., \& van den Linden, A. (1998). Recovery of the energy metabolism after a hypoxic challenge at different temperature conditions: a ${ }^{31} \mathrm{P}$ nuclear magnetic resonance spectroscopy study with common carp. Comparative Biochemistry and Physiology Part A: Molecular \& Integrative Physiology, 120(1), 143-150.

Burggren, W. W., \& Randall, D. J. (1978). Oxygen uptake and transport during hypoxic exposure in the sturgeon Acipenser transmontanus. Respiration Physiology, 34(2), 171-183.

Cech, J. J., Mitchell, S. J., \& Wragg, T. E. (1984). Comparative growth of juvenile white sturgeon and striped bass: effects of temperature and hypoxia. Estuaries, 7(1), 12-18.

Chang, Y. J., Jeong, M. H., Min, B. H., Neill, W. H., \& Fontaine, L. P. (2005). Effect of photoperiod, temperature, and fish size on oxygen consumption in the black porgy Acanthopagrus schlegelii. Journal of Fish Science and Technology, 8, 142-150.

Cruz-Neto, A. P., \& Steffensen, J. F. (1997). The effects of acute hypoxia and hypercapnia on oxygen consumption of the freshwater European eel. Journal of Fish Biology, 50, 759-769.

De las Heras, V., Martos-Sitcha, J. A., Yúfera, M., Mancera, J. M., \& Martínez-Rodríguez, G. (2015). Influence of stocking density on growth, metabolism and stress of thicklipped grey mullet (Chelon labrosus) juveniles. Aquaculture, 448, 29-37.

El-Sayed, A. F. M. (2002). Effects of stocking density and feeding levels on growth and feed efficiency of Nile tilapia (Oreochromis niloticus L.) fry. Aquaculture Research, 33(8), 621-626.

Fry, F. E. J. (1971). The effect of environmental factors on the physiology of fish. In W. S. Hoar \& D. J. Randall (Eds.), Fish Physiology, Vol. VI. Environmental relations and behavior. New York, United States: Academic Press. 
Oseanologi dan Limnologi di Indonesia 2019 4(2):79-87

García-Trejo, J. F., Peña-Herrejon, G. A., SotoZarazúa, G. M., Mercado-Luna, A., Alatorre-Jácome, O., \& Rico-García, E. (2016). Effect of stocking density on growth performance and oxygen consumption of Nile tilapia (Oreochromis niloticus) under greenhouse conditions. Latin American Journal of Aquatic Research, 44(1), 177183.

Herbert, N. A. \& Steffensen, J. F. (2005). The response of Atlantic cod, Gadus morhua, to progressive hypoxia: fish swimming speed and physiological stress. Marine Biology, 147(6), 1403-1412.

Jobling, M. (1993). Bioenergetics: feed intake and energy partitioning. In J. C. Rankin \& F. B. Jensen (Eds.), Fish Ecophysiology, Fish and Fisheries Series 9 (pp. 16-28). London, England: Chapman \& Hall.

Jobling, M. (1994). Fish bioenergetics. London, England: Chapman \& Hall.

Jorgensen, E. H., Christiansen, J. S., \& Jobling, M. (1993). Effects of stocking density on food intake, growth performance and oxygen consumption in Arctic charr (Salvelinus alpinus). Aquaculture, 110(2), 191-204.

Kawamoto, N. (1977). Fish physiology. Tokyo, Japan: Koseisha-Koseikaku (in Japanese).

Laursen, D. C., Silva, P. I., Larsen, B. K., \& Höglund, E. (2013). High oxygen consumption rates and scale loss indicate elevated aggressive behaviour at low rearing density, while elevated brain serotonergic activity suggests chronic stress at high rearing densities in farmed rainbow trout. Physiology \& Behavior, 122, 147-154.

Lefevre, S., Wang, T., Phuong, N. T., \& Bayley, M. (2011). Hypoxia tolerance and partitioning of bimodal respiration in the striped catfish (Pangasianodon hypophthalmus). Comparative Biochemistry and Physiology Part A: Molecular \& Integrative Physiology, 158(2), 207-214.

Lefevre, S., Phuong, N. T., Wang, T., \& Bayley, M. (2012). Effects of hypoxia on the partitioning of oxygen uptake and the rise in metabolism during digestion in the airbreathing fish Channa striata. Aquaculture, 364, 137-142.

Li, D., Liu, Z., \& Xie, C. (2012). Effect of stocking density on growth and serum concentrations of thyroid hormones and cortisol in Amur sturgeon, Acipenser schrenckii. Fish Physiology and Biochemistry, 38(2), 511520.
Magnoni, L. J., Eding, E., Leguen, I., Prunet, P., Geurden, I., Ozório, R. O., \& Schrama, J. W. (2018). Hypoxia, but not an electrolyteimbalanced diet, reduces feed intake, growth and oxygen consumption in rainbow trout (Oncorhynchus mykiss). Scientific Reports, 8(1), 4965.

Mamun, S. M., Focken, U., \& Becker. K. (2013). A respirometer system to measure critical and recovery oxygen tensions of fish under simulated diurnal fluctuations in dissolved oxygen. Aquaculture International, 21, 3144.

Millán-Cubillo, A. F., Martos-Sitcha, J. A., RuizJarabo, I., Cárdenas, S., \& Mancera, J. M. (2016). Low stocking density negatively affects growth, metabolism and stress pathways in juvenile specimens of meagre (Argyrosomus regius, Asso 1801). Aquaculture, 451, 87-92.

Mishrigi, S., \& Kubo, T. (1978). Effects of territoriality on oxygen consumption in Tilapia nilotica. Bulletin of the Faculty of Fisheries Hokkaido University, 29(4), 308312.

Ott, M. E., Heisler, N., \& Ultsch, G. R. (1980). A re-evaluation of the relationship between temperature and the critical oxygen tension in freshwater fishes. Comparative Biochemistry and Physiology Part A: Physiology, 67(3), 337-340.

Perry, S. F., Jonz, M. G., \& Gilmour, K. M. (2009). Chapter 5. Oxygen sensing and the hypoxic ventilatory response. In J. G. Richards, A. P. Farrell, \& C. J. Brauner (Eds.), Fish Physiology. Vol. 27: Hypoxia (pp. 193-253). New York, United States: Academic Press.

Petersen, L. H., \& Gamperl, A. K. (2010). Effect of acute and chronic hypoxia on the swimming performance, metabolic capacity and cardiac function of Atlantic cod (Gadus morhua). Journal of Experimental Biology, 213(5), 808-819.

Pichavant, K., Person-Le-Ruyet, J., Le Bayon, N., Severe, A., Le Roux A., Quemener, L., Maxime, V., Nonnotte, G., \& Boeuf, G. (2000). Effects of hypoxia on growth and metabolism of juvenile turbot. Aquaculture, 188(1-2), 103-114.

Pichavant, K., Person-Le-Ruyet, J., Bayon, N. L., Severe, A., Roux, A. L., \& Boeuf, G. (2001). Comparative effects of long-term hypoxia on growth, feeding and oxygen consumption in juvenile turbot and European sea bass. Journal of Fish Biology, 59(4), 875883. 
Iswantari et al.

Pörtner, H. O., Heisler, N., \& Grieshaber, M. K. (1985). Oxygen consumption and mode of energy production in the intertidal worm Sipunculus nudus L.: definition and characterization of the critical $\mathrm{PO}_{2}$ for an oxyconformer. Respiration Physiology, 53(3), 361-77.

Prakoso, V. A., Ath-thar, M. H. F., Subagja, J., \& Kristanto, A. H. (2016). Pertumbuhan ikan uceng (Nemacheilus fasciatus) dengan padat tebar berbeda dalam lingkungan ex situ. Jurnal Riset Akuakultur, 11(4), 355362.

Prakoso, V. A., \& Chang, Y. J. (2018). Effects of hypoxia on oxygen consumption of tilapia fingerlings (Oreochromis niloticus). Oseanologi dan Limnologi di Indonesia, 3(2), 165-171.

Rahman, M. M., Mondal, D. K., Amin, M. R., \& Muktadir, M. G. (2016). Impact of stocking density on growth and production performance of monosex tilapia (Oreochromis niloticus) in ponds. Asian Journal of Medical and Biological Research, 2(3), 471-476.

Randall, D. (1982). The control of respiration and circulation in fish during exercise and hypoxia. Journal of Experimental Biology, 100(1),275-288.

Rombough, P. J. (1988). Growth, aerobic metabolism, and dissolved oxygen requirements of embryos and alevins of steelhead, Salmo gairdneri. Canadian Journal of Zoology, 66(3), 651-660.

Ronald, N., Gladys, B., \& Gasper, E. (2014). The effects of stocking density on the growth and survival of Nile tilapia (Oreochromis niloticus) fry at son fish farm, Uganda. Journal of Aquaculture Research and Development, 5(2), 222. doi:10.4172/21559546.1000222

Rees, B. B., Boily, P., \& Williamson, L. A. C. (2009). Exercise- and hypoxia-induced anaerobic metabolism and recovery: a student laboratory exercise using teleost fish. Advances in Physiology Education, 33(1), 72-77.

Ren, Y., Wen, H., Li, Y., Li, J., He, F., \& Ni, M. (2017). Effects of stocking density on lipid deposition and expression of lipid-related genes in Amur sturgeon (Acipenser schrenckii). Fish Physiology and Biochemistry, 43(6), 1707-1720.

Richards, J. G. (2011). Physiological, behavioral and biochemical adaptations of intertidal fishes to hypoxia. Journal of Experimental Biology, 214(2),191-199.

Ruer, P. M., Cech Jr, J. J., \& Doroshov, S. I. (1987). Routine metabolism of the white sturgeon, Acipenser transmontanus: effect of population density and hypoxia. Aquaculture, 62(1), 45-52.

Sahoo, S. K., Giri, S. S., \&. Sahu, A. K. (2004). Effect of stocking density on growth and survival of Clarias batrachus (Linn.) larvae and fry during hatchery rearing. Journal of Applied Ichthyology, 20(4), 302-305.

Salas-Leiton, E., Anguis, V., Manchado, M., \& Canavate, J. P. (2008). Growth, feeding and oxygen consumption of Senegalese sole (Solea senegalensis) juveniles stocked at different densities. Aquaculture, 285(1-4), 84-89.

Smith, K. J., \& Able, K. W. (2003). Dissolved oxygen dynamics in salt marsh pools and its potential impacts on fish assemblages. Marine Ecology Progress Series, 258, 223 232.

Subagja, J., Prakoso, V. A., Arifin, O. Z., \& Kristanto, A. H. (2019). Pengaruh perbedaan padat tebar larva terhadap pertumbuhan dan sintasan pada ikan uceng (Nemacheilus fasciatus). Berita Biologi, xx, xx-xx.

Suresh, A. V., \& Lin, C. K. (1992). Effect of stocking density on water quality and production of red tilapia in a recirculated water system. Aquacultural Engineering, 11(1), 1-22.

Svendsen, J. C., Steffensen, J. F., Aarestrup, K., Frisk, M., Etzerodt, A., \& Jyde, M. (2012). Excess posthypoxic oxygen consumption in rainbow trout (Oncorhynchus mykiss): recovery in normoxia and hypoxia. Canadian Journal of Zoology, 90(1), 1-11.

Szczepkowski, M., Szczepkowska, B., \& Piotrowska, I. (2011). Impact of higher stocking density of juvenile Atlantic sturgeon, Acipenser oxyrinchus Mitchill, on fish growth, oxygen consumption, and ammonia excretion. Archives of Polish Fisheries, 19(2), 59-67.

Tzaneva, V., Bailey, S., \& Perry, S. F. (2011). The interactive effects of hypoxemia, hyperoxia, and temperature on the gill morphology of goldfish (Carassius auratus). American Journal of Physiology-Regulatory, Integrative and Comparative Physiology, 300(6), 344-1351.

Utami, P. (2017, September 15). Jaga populasi, anakan ikan Uceng yang jadi ikon 
Oseanologi dan Limnologi di Indonesia 2019 4(2):79-87

Temanggung ini akan disebar ke sungai. Retrieved January 10, 2019, from https://jateng.merdeka.com/perikanan/jagapopulasi-anakan-ikan-uceng-yang-jadiikon-temanggung-ini-akan-disebar-kesungai-170915w.html

Wardhana, A. \& Riana. (2015, December 7). Berpotensi bagus, ikan uceng akan dijadikan ikon daerah. Retrieved January 10, 2019, from https: //www. jitunews.com/read/ 26619/berpotensi-bagus-ikan-uceng-akandijadikan-ikon-daerah

Wares, W. D., \& Igram, R.(1979). Oxygen consumption in the fathead minnow (Pimephales promelas Rafinesque) - I: Effects of weight, temperature, group size, oxygen level and opercular movement rate as a function of temperature. Comparative Biochemistry and Physiology Part A: Physiology, 62(2), 351-356. 